\title{
„NEJSME TAK DOBŘİ, JAK SI MYSLÍME“ ABSOLVENTI ŠKOL V KONTEXTU DISKUSE O KVALITĚ VZDĚLÁVÁNÍ V RAKOUSKU
}

\author{
RENATE SEEBAUEROVÁ
}

\begin{abstract}
Anotace: Současná diskuse o standardech vzdělávání se pohybuje mezi snahami o autonomii a interní rozvoj školy na jedné straně a implementováním národní evaluace kvality na straně druhé. Ve skutečnosti kompetence ziskané ve škole nejsou u mnoha žáků postačující $k$ účasti $v$ procesu celoživotního vzdělávání. Velké rozdily jsou shledávány $v$ učebních výkonech žáků $v$ rüzných třídách, školách a regionech, a to dokonce i uvnitř škol stejného druhu. V Rakousku se v současné době začíná pracovat na různých návrzích standardi̊ vzdělávání. Sféra hospodárství v souvislosti s tím oprávněně požaduje, aby absolventi disponovali tzv. „kličovými kvalifikacemi“" (Schlüsselqualifikation). Po několika pilotních fázích se vzdělávací standardy mají začít použivat od roku 2008 v náhodně vybraném souboru $30 \%$ žáků 1. stupně a 30 \% žáků 8. tříd základních škol.
\end{abstract}

Kličová slova: kvalita vzdělávání, kličcové kompetence, PISA, vzdělávací standardy

Abstract: On the one hand the current discussion about standards in education is to be seen in the field of tension concerning attempts for autonomy and internal school development, on the other hand, the implementation of a high-quality evaluation on a national level is being on the agenda. With many pupils the competences acquired at school are not adequate for their participation in the process of lifelong learning; in fact the performances show great differences between classes, schools and areas, even within the identical types of schools. The regional differences in Austria are too great; the Ministry of Education and school boards on the level of the federal provinces partially work on different drafts of standards in education; in addition trade and industry - with good reason - demand so-called "key competences" with school leavers. After piloting the standards for a number of years, a random sample of $30 \%$ of the fourth-year pupils of elementary schools and $30 \%$ of the eighth-year pupils of lower secondary schools will be tested for the first time in 2008.

Key words: quality in education, key competence, PISA, educational standards 


\section{Diskuse o kvalitě mezi autonomií škol a vzdělávacími standardy}

Ačkoliv výzkumy TIMSS, PISA a další nevyvolaly v Rakousku podobné šokující reakce jako v Německu, přece jen vedly k pozvolné změně pohledu na význam výkonu žáků, přičemž větší pozornost se začala věnovat srovnávacím studiím. Téměř nemyslitelnou byla představa, že se podaří do jednoho systému etablovat externě definované standardy spolu s empirickými srovnávacími výzkumy (srov. Specht 2005). Rovněž výzkum PISA 2003 ukázal, že v rakouských školách je př́liš mnoho žáků, jejichž kompetence získané ve škole nejsou postačující pro zapojení do procesu celoživotního vzdělávání; že rozdíly v učebních výkonech mezi třídami, školami a regiony $\mathrm{v}$ rámci stejných druhů škol jsou značné; že hodnocení výkonů je zatíženo velkou nespravedlností (srov. Specht 2005).

Jako informace ze zákulisí může být $\mathrm{v}$ krátkosti načrtnuta tradice zajištování a rozvoje kvality, jak fungovala $v 90$. letech 20 . století. Zajištování a rozvoj kvality bylo řízeno prostřednictvím zákonů, zdrojů, učebních plánů - šlo o řízení vstupů. Neexistovaly žádné centrální nebo standardizované závěrečné zkoušky, např. při ukončení nižší sekundární školy (Hauptschule) nebo u maturity. Neprovádělo se ani žádné systematické (empirické) kontrolování výstupů - např. pomocí národních testů.

Co se kvality ve vzdělávání týče, za hlavní př́stup byl považován „rozvoj školy“ (Schulentwicklung), který se zaměřoval na rozvíjení kvality na úrovni konkrétních škol (srov. www.qis.at). Jako výzkumné paradigma se etabloval akční výzkum a kvalitativní studie, $\mathrm{v}$ nichž se pozornost zaměřovala na organizaci a na procesy, které $\mathrm{v}$ ní probíhají. Rozvíjely se výzkumy, $\mathrm{v}$ nichž byla věnována pozornost charakteristickým rysům „dobrých škol“, tematizována byla sebereflexe a profesionalizace.

V roce 2000 vytyčila konzervativní spolková vláda ve svém vládním programu následující body:

- „Udržení a rozvoj vysokého kvalitativního standardu škol zavedením školního programu a evaluace kvality (veřejný charakter metod a výsledků), stanovením národních výkonnostních standardů a zavedením sešitů povinností (Pflichtenheften), srovnáváním výkonnosti škol.

- Odborné (vědecké) vypracování a vyhodnocování testů určených k prověřování kulturních technik, znalostí cizích jazyků a kvalifikací v oblasti informačních technologií.

- Další posílení autonomie škol“ (cit. podle Spechta 2005).

Tento program byl zaváděn ve fázi rozvoje školy, kdy se téměř po jedno desetiletí hovořilo o „autonomii“ a o „vnitřním rozvoji školy“ a kdy téměř došlo k tomu, že školám bude svěřeno více zodpovědnosti za vlastní rozvoj kvality. Specht (2005) považuje tyto programové body za kulturní zlom, který se dotkne nejen škol, ale také školské správy a pedagogické vědy. 


\section{Co od absolventů škol očekává hospodářství}

Na počátku 3. tisíciletí formulují hospodářská grémia čím dál častěji svá očekávání vůči absolventům škol: „Učni - dobrý výdělek za málo vzděláni", takový nadpis dal Bräuer (2003) jednomu článku ve Vídeňském hospodářském zpravodaji elektrotechniků: „Relace, která se stala smutnou každodenností. Mnohým absolventům 9. ročníku povinného vzdělávání chybi velká část všeobecného vzdělání. Co očekává naše hospodárství od absolventư škol? Nic, co by se nedalo zvládnout. K základním odborným kompetencím patři kromě zvládnutí mateřského jazyka použivání jednoduchých početních postupu․ Trojčlenka a počítání procent by neměly být pro nastávající učně žádným problémem. Existují odborné, osobnostní a sociální kompetence, které musí výrobní podniky u absolventů škol předpokládat. Stále důležitějši roli hrají prírodovědné znalosti, základní znalosti angličtiny a práce s novými médii. Já považuji za nepostradatelné vlastnosti spolehlivost, ochotu učit se a pracovat, stejně jako pečlivost a svědomitost. K nutným predpokladưm patři také určitá míra zodpovědnosti. Vedle odborné a sociální kompetence je důležitá také rada základních hodnotových postojů v pracovním životě. Úspěch podniku závisí také na vůli zaměstnanců spolupracovat" (Bräuer 2003, s. 4).

V témže roce zadává Spolkové ministerstvo pro vědu, vzdělání a kulturu ibwstudii „Efekty prípravného vzdělávání na polytechnické škole s ohledem na prechod absolventů do učňovského vzděláváni" (srov. Schneeberger et al. 2003).

Pracovní skupina „Škola \& hospodářstvi“" Hospodářské komory Horního Rakouska prezentuje dne 4. října 2004 ve Freistadtu př́spěvek „Co očekává hospodárství od absolventů škol“. Přitom je jasně vyjádřeno, že kromě „znalostí a dovednosti“ je velká pozornost věnována takzvaným „klíčovým kvalifikacím“ (odborná kompetence Sachkompetenz, sociální kompetence - Sozialkompetenz a osobnostní kompetence - Selbskompetenz).

\section{Vzdělávací standardy v Rakousku - pokus o vymezení pojmu}

Jako tzv. „rakouské řešeni“ byla v letech 2001-2003 vytvořena tzv. „řídící skupina“ na úrovni svazu a jednotlivých spolkových zemí, která měla koordinovat tvorbu standardů vzdělávání. Oddělení ministerstva zabývající se řízením škol kromě toho zř́dilo pracovní skupiny úředníků, praktiků a expertů, které byly pověřeny vypracováním vzdělávacích standardů pro oblasti: čtení a matematika na výstupu primární školy; němčina, angličtina a matematika na výstupu nižší sekundární školy. Specht (2005) vymezuje následující (implicitní) principy, které by tvorba standardů měla respektovat:

- vytvářet co možná nejmenší napětí a konflikty vzhledem $\mathrm{k}$ existující kultuře školy;

- ze stávajících učebních plánů „destilovat“ základní (jádrové) kompetence; 
- označit standardy jako „orientační standardy“;

- napomáhat při autoevaluaci na školách;

- zachovávat kontinuitu s ohledem na dosavadní vývoj (srov. Specht 2005).

Pod heslem „Kdo se přestává stávat lepším, ten přestal být dobrým“ zahájilo př́íslušné ministerstvo nasazením „Komise budoucnosti“ v roce 2003 kvalitativní ofenzívu - s cílem trvale zlepšovat kvalifikace a kompetence žáků a zajistit přicházející generaci šance do budoucnosti.

Výsledky výzkumu PISA zřetelně ukázaly, že tzv. „ř́izení na vstupu“ samo o sobě nevede $\mathrm{k}$ žádoucím výsledkům vzdělávacího systému. $\mathrm{Z}$ tohoto důvodu se také v Německu, ve Švýcarsku a v mnoha dalších evropských státech přistupuje ke tvorbě vzdělávacích standardů.

Obecně je pojmem „standard“ chápán jako měřítko - kotva, norma, kritérium nebo určitý předem stanovený výkon. Je třeba rozlišovat mezi standardy, které stanovují určité normy pro vyučování a mají orientační charakter, a mezi standardy, které mají povahu testu a jejichž prostřednictvím se ve 4. a 8. ročníku měří úroveň výkonu žáků.

Vzdělávací standardy stanovují, jakými kompetencemi by měli žáci disponovat na výstupu ze čtvrtého ročníku primární školy (Volksschule) a ze čtvrtého ročníku nižší sekundární školy (Hauptschule nebo Gymnasium) v základních oborech, jako jsou němčina, matematika a angličtina.

Vzdělávací standardy

- se koncentrují do základních oblastí vyučovacího předmětu a popisují očekávané učební výsledky;

- kladou zvláštní důraz na trvalé osvojení základních kompetencí;

- formulují úkoly na střední úrovni;

- poskytují učitelům prostor pro individuální přistup ke specifikám tř́ídy (zachování autonomie učitelů v používání metod).

Vzdělávací standardy vyžadují průběžné ověřování, aby mohly být funkční i s ohledem na rozvíjení kvality. Odborníci vytvářejí odpovídající sbírky úkolů a testů pro 4. a 8. ročník školy. Výsledky těchto testů mají velký význam pro vzdělávací politiku, protože umožňují transparentnost rozvoje kvality na školách. Vzdělávací standardy etablují také nové formy srovnatelnosti učebních výsledků a skládání účtů (akontabilita) v rakouském vzdělávacím systému: není popisován pouze aktuální stav, poukazuje se také na další rozvoj vzdělávacího systému (srov. bm:bwk 2004).

Abychom lépe porozuměli tomu, co v rakouském pohledu vyjadřuje pojem vzdělávací standardy, nabídneme níže i negativní vymezení.

Vzdělávací standardy:

- nestanovují, co je dobrá výuka; ovlivňují výuku nepřímo prostřednictvím daného pedagogického rámce a s ohledem na učební výsledky (outcome);

- nereglementují vyučování a učení, ani proces školního vzdělávání; 
- nezrušují pedagogickou zodpovědnost za vyučování, za požadavky a za hodnocení;

- nepodávají vyčerpávající popis vzdělávacích cílů, nýbrž definují klíčové kompetence;

- nedotýkají se autonomních možností rozvoje jednotlivých škol (zaměření školy, školní profil atp.);

- nejsou nástrojem evaluace (ranking) kvality, nýbrž pomocným prostředkem $\mathrm{k}$ autoevaluaci a hledání orientace školy a učitelů;

- nejsou náhradou za hodnocení výkonu, ani nástrojem pro rozřazování do výkonnostních skupin.

\section{Vzdělávací standardy $\mathrm{v}$ pilotních fázích}

V létě roku 2002 předložila skupina odborníků první pracovní návrhy vzdělávacích standardů. Přepracované návrhy byly vyzkoušeny na podzim roku 2003 na 18 pilotních školách v 8 . ročnících a na jaře roku 2004 také ve více než 30 primárních školách (Volksschulen) v tzv. pilotní fázi I (do června 2004). Evaluaci pilotáže provedlo Centrum pro rozvoj školy v Grazu. Ve víceleté pilotní fázi II (počínaje školním rokem 2004/5) byly návrhy vyzkoušeny ve všech spolkových zemích.

V pilotní fázi II se na Pedagogickém institutu v Linzi buduje internetový systém pro učitele, kteři se se svými tř́dami nedostali do náhodného výběru, chtěli by však dobrovolně provést autoevaluaci.

Po vyhodnocení pilotní fáze II budou zveřejněna zákonná ustanovení pro ověřování vzdělávacích standardů ve čtvrtých a osmých ročnících. Po skončení pilotní fáze (2008) je plánováno provádět ročně ověřování standardů na vzorku náhodně vybraných žáků čtvrtých a osmých ročníků (týká se to $30 \% 4$. a 8. ročníků, z toho ve 4. ročníku $15 \% \mathrm{v}$ němčině nebo matematice a $\mathrm{v} 8$. třídě $10 \% \mathrm{v}$ němčině, angličtině nebo matematice, přičemž $\mathrm{v}$ jedné škole bude testován vždy jeden předmět).

\section{Spolkové vzdělávací standardy a standardy městské školní rady Vídně}

W. Gröpel, zemský školní inspektor pro všeobecně-vzdělávací povinné školy, popisuje pět rozdílů „vídeňských standardü“ oproti „spolkovým standardům“ (srov. SSRfW 2004):

- Ročníky: Vídeňský model nepředpokládá standardy pro 8. (4.) ročník, nýbrž standardy popř. konkretizace, které jsou formulovány vzestupně pro 5. až 8. ročník. Tímto způsobem má být podporováno a usnadněno pedagogické působení učitelů, má jim být nabídnut základ pro hodnocení orientované na učební cíle. Celkově se vídeňské vzdělávací standardy ještě výrazněji orientují na platné učební plány. 
- Stupně kompetencí: Spolkové standardy jsou k dispozici pro tři stupně kompetencí, které odpovídají výkonnostním skupinám. Vídeňský koncept nepředpokládá, že by se rozlišovaly úrovně výkonu k prokazování kvalitativních rozdílů plnění standardů, nebơ obtížnost je určována různými faktory a striktní přiřazení k ustrnulým výkonnostním skupinám neodpovídá pedagogickým záměrům individualizujícího vyučování vídeňského školství.

- Kompetence přesahující predmèty/obory: Vídeňské standardy formulují také standardy učebního a pracovního chování a „dynamických schopností; čímž je přihlédnuto především $\mathrm{k}$ problémům $\mathrm{v}$ městských oblastech a $\mathrm{k}$ požadavku celoživotního učení.

- Vídeňské standardy nechtějí omezovat prostor pro jednání učitelů zadáváním konkrétních príkladů; sbírka príkladů uplatnění standardů má vzniknout z praktické práce ve školách.

- Vídeňské vzdělávací standardy podporují a konkretizují spolkové standardy (srov. SSRfW 2004, s. 6an).

\section{Dynamické schopnosti, učební a pracovní chování - specifika vídeňských standardů}

V rakouském učebním plánu nižšího sekundárního stupně je v oblasti úkolů školy poukázáno na tzv. „dynamické schopnosti“ (dynamische Fähigkeiten). Je tím míněna „schopnost a ochota prevzit zodpovědnost, spolupracovat s ostatnimi, vyvíjet iniciativu a spolupracovat na utvárení sociálního života uvnitř i vně školy ...". Podle Klipperta (1996) dynamické schopnosti zahrnují metodickou kompetenci a komunikační kompetenci a schopnost pracovat $\mathrm{v}$ týmu. $\mathrm{K}$ těmto dílčím oblastem bylo formulováno 18 předmětově neutrálních vzdělávacích standardů (doslovně pro 5. až 8. ročník) - jak z pohledu učitelů, tak i žáků.

Standardy učebního a pracovního chování vznikly ve spolupráci zástupců škol povinného vzdělávání a odborných škol - vycházejí ze skutečnosti, že nedostatky v pracovním chování u absolventů základních škol bývají nahlíženy jako důvod potíží při přestupu mezi školami.

Formulováním učebních cílů pro oblast učebního a pracovního chování lze očekávat, že

- se nutně stanou součástí vyučování;

- žákům bude upřesněno, co se v této oblasti od nich očekává, nebot tyto vzdělávací obsahy mohou být konkrétně tematizovány a reflektovány;

- žáci budou vedeni k rozvoji sebekritiky vzhledem k učebnímu a pracovnímu chování (srov. SSRfW 2004, s. 12 an.). 


\section{7. „PISA“ a „vzdělávací standardy“ - porovnání}

Oba nástroje, jak koncepce, na níž je založen výzkum PISA, tak i vzdělávací standardy jsou tzv. regulačními standardy (Regelstandards), které vymezují očekávané kompetence žáků $\mathrm{v}$ určitých bodech jejich vzdělávací dráhy. Oba tyto nástroje chápou např. matematickou gramotnost shodně (od zaměření na početní dovednosti $\mathrm{k}$ řešení problémů). Jak PISA, tak i vzdělávací standardy jsou založeny na testech, které pracují s rozdílnými typy úloh. Oba nástroje slouží systémové evaluaci, tzv. „monitoringu“" (srov. Lucyshyn 2006, Kubinger et al. 2006).

Tab. 1 zachycuje rozdíly mezi oběma testovacími nástroji z hlediska jejich pedagogické orientace, srovnatelnosti a zpětné vazby o výsledcích:

\begin{tabular}{|c|c|c|}
\hline & PISA & Rakouské vzdělávací standardy \\
\hline $\begin{array}{l}\text { Peda- } \\
\text { gogická } \\
\text { orientace }\end{array}$ & $\begin{array}{l}\text { Těžiště spočivá ve } \\
\text { funkční aplikaci zna- } \\
\text { lostí ve zcela rozdílných } \\
\text { kontextech. } \\
\text { Nepřihlíží se k učebním } \\
\text { plánům zúčastněných } \\
\text { zemí. }\end{array}$ & $\begin{array}{l}\text { Učební plán: vzdělávací a učební úlohy, } \\
\text { předepsané obsahové oblasti a př́islušný } \\
\text { model kompetencí. }\end{array}$ \\
\hline $\begin{array}{l}\text { Srovnatel- } \\
\text { nost }\end{array}$ & Mezinárodní. & $\begin{array}{l}\text { Uvnitř rakouského vzdělávacího sys- } \\
\text { tému s ohledem na různé aspekty (dle } \\
\text { druhů škol - Volksschule, AHS, Haupts- } \\
\text { chule); u Hauptschule: mezi výkon- } \\
\text { nostními skupinami; regionálně, podle } \\
\text { spolkových zemí; školy, učitelé, žáci. }\end{array}$ \\
\hline $\begin{array}{l}\text { Zpětná } \\
\text { vazba }\end{array}$ & $\begin{array}{l}\text { Podpora pro školy není } \\
\text { k dispozici. }\end{array}$ & $\begin{array}{l}\text { Podpora - především pro školy - bude } \\
\text { k dispozici. Žáci dostanou zpětnou vaz- } \\
\text { bu o výsledcích - silné a slabé stránky } \\
\text { jsou popisovány tak detailně, že lze } \\
\text { odhalit případnou potřebu podpory. } \\
\text { Připravují se speciální nabídky dalšího } \\
\text { vzdělávání a podpůrné programy pro } \\
\text { učitele. }\end{array}$ \\
\hline
\end{tabular}

Tab. 1: „PISA“ a „VZdělávací standardy“ - porovnání 


\section{Kritické hlasy v učitelských kruzích}

„Učitelé proti vzdělávacím standardi̊m - podle studie nebude výuka lepší - také reditelé jsou proti - učitelé na pilotních školách ještě kritičtějši "oznamuje deník Standard. Podle studie Rudolfa Beera zaujímají učitelé a ředitelé škol vůči plánovaným vzdělávacím standardům převážně negativní postoj. „Podle názoru téměr 900 dotázaných vídeñských pedagogů nezaručují standardy lepši výuku, nepřispívají ke škole beze strachu, $k$ vyšší kvalitě ani $k$ větší transparentnosti školní práce popř. profesionalitě učitelů. ... Více než tři čtvrtiny učitelů uvedlo, že standardy jen sotva zlepši žákům šance na vzdělání, 87 \% pochybovalo, že díky nim se budou žáci učit lépe, 82 \% odmitlo názor, že vzdělávací standardy zlepší kvalitu výuky. Více než polovina zastávala názor, že vzdělávací standardy nebudou stimulovat kvalitu výuky na školách. ... Kromè toho se ukázalo, že všechny skupiny učitelů se vưči vzdělávacím standardům distancovaly: Nejskeptičtějši prìtom byli učitelé 2. stupně (Hauptschule), naproti tomu nejotevřenější byli učitelé AHS. O něco méně kritičtí, ovšem převážnè rovněž skeptičtí, byli ředitelé škol. Naproti tomu věk učitelů nemèl žádný vliv.... Nedostatečná informovanost o standardech patrně není di̊vodem jejich odmítnutí: Učitelé na pilotních školách, na nichž již standardy byly vyzkoušeny, jsou totiž dokonce ještě kritičtější. Negativní postoj pedagogů se projevuje také $v$ nízké ochotě ke spolupráci při implementování standardů - asi 70 procent pedagogů uvedlo, že standardy nechtějí podpořit, popř. jen málo" (Der Standard ze dne 30. 11.2006).

\section{Vzdělávací standardy a důsledky pro školu}

W. Gröpel (srov. SSRfW 2004) chápe vzdělávací standardy v prvé řadě jako „... nástroj ověrování učebního pokroku vlastních žákư“, který ukáže, „...jak dalece bylo dosaženo stanovených cílů - ziskání určitých oborových a nadoborových kompetenci" (Gröpel in SSRfW 2004, s. 7). Vídeňský model zdůrazňuje přednost autoevaluace. Jak dále zdůrazňuje citovaný autor, „...v žádném př́padě by vývoj neměl směřovat $k$ tomu, že by docházelo $k$ následným zveřejnèním a hodnocení. Benchmarking - tedy srovnání umístění škol mezi sebou - se jeví jako více než problematické vzhledem k rozdílné žákovské populaci ve městě a na venkově, jakož i vzhledem ke stále rostoucímu podílu žáků s jiným než německým mateřským jazykem. Formulováním vzdělávacích standardů však $v$ žádném př́padě nemá být učitelưm odebrána dosavadní didaktická a metodická svoboda; $v$ podobě standardỉ jim má být dán do ruky flexibilní orientační rámec pro plánování a realizaci výuky a současně nástroj pro trvalé zajištění efektů výuky" (Gröpel in SSRfW 2004, s. 7).

Je nutno uvést, že diskuse o vzdělávacích standardech vedla $\mathrm{k}$ uvědomění si nutnosti výraznější orientace na výsledky rakouských škol. Jistě bude ještě trvat, než se standardy stanou samozřejmým nástrojem rozvoje kvality výuky. 


\section{Literatura}

BEER, R. Bildungsstandards. Einstellungen von Lehrerinnen und Lehrern. Lit Verlag : Wien, 2006.

BRÄUER, Ch. Lehrlinge - viel Verdienst für wenig Bildung. In E NERV. Wiener Wirtschaftsreport für Elektrotechniker, 2003, s. 4.

DAS ZUKUNFTSMINISTERIUM BM:BWK (Hg.). Bildungsstandards. Ein weiterer Qualitätssprung für das österreichische Schulwesen. (Broschüre, 6 Seiten), 2004.

Der Standard ze dne 30. 11. 2006.

KLIPPERT, H. Methodentraining. Übungsbausteine für den Unterricht. WeinheimBasel : Beltz, 1996.

KUBINGER, K. D. et al. Standardtests zu den Bildungsstandards in Österreich. Wissenschaftlicher Hintergrund und Hinweise zur Interpretation der Ergebnisse der Standard-Tests. Test- und Beratungsstelle, Arbeitsbereich Psychologische Diagnostik. Wien : Univ. Wien, 2006.

LUCYSHYN, J. Moderatoren-Manual. Salzburg : bm:bwk - Projektmanagement Bildungsstandards. Manuskript unv, 2006.

SCHNEEBERGER, A.; KASTENHUBER, B.; PETANOVITSCH, A. Vorbildungseffekte der Polytechnischen Schule im Hinblick auf die Überleitung ihrer Absolventen in die Lehrlingsausbildung. Ergebnisse einer Lehrbetriebsbefragung, Wien : IBW, 2003.

SCHULE \& WIRTSCHAFT, AREBITSKERIS FREISTADT Welcome to the job. Erwartungen der Wirtschaft an Schulabsolventen. Power-Point-Präsentation (38 Seiten), 2004.

SPECHT, W. Von den Mühen der Ebene. Entwicklung und Implementation von Bildungsstandards in Österreich. Power-Point-Präsentation, AEPF-Tagung, Salzburg, 19. 9. 2005.

STADTSCHULRAT FÜR WIEN (Hg.). Arbeit mit Bildungsstandards in Wien. Wien : Stadtschulrat, 2004. 